\title{
Editorial: PPP special issue - International Perspectives on Fuel Poverty
}

\author{
Aimee Ambrose, * Will Eadson and Jan Gilbertson \\ Sheffield Hallam University
}

\begin{abstract}
Despite the commitments of successive UK governments to end fuel poverty by 2016 , over ten per cent of UK households were deemed to be in fuel poverty in 2015 (DECC, 2015). Although comparisons over time have been rendered virtually impossible by changes to the way fuel poverty is defined and measured, it is clear that the target of fuel poverty eradication remains elusive., The winter of 2014/15 saw excess winter deaths reach their highest winter levels since 1999/00 (ONS, 2016). Evidence suggests that around a fifth of these 43,500 deaths are attributable to cold homes (Marmot Review Team, 2011) and are entirely preventable. However, excess winter deaths are only part of the picture and fuel poverty is a longstanding and pervasive health issue contributing to wider social and health inequalities. We remain far from a solution to this great social injustice which disproportionately affects the most vulnerable in society.
\end{abstract}

Academic interest in the fuel poverty debate has proved as tenacious as the problem itself and our understanding of the nature, extent and consequences of fuel poverty grows increasingly detailed and nuanced, informing the work of policy makers and a growing body of charities, lobbyists and pressure groups seeking to hold government to account. The community of those seeking to better understand and develop solutions to fuel poverty is now truly multidisciplinary in nature, straddling sociology; medicine and public health; engineering; geography; architecture and planning; engineering; urban studies; economics and business. It is also, as this special issue seeks to underline, an increasingly international community.

Fuel poverty as a concept can be traced back to the UK in the early 1980s, when it was first recognised that lower income consumers needed to spend a larger percentage of their income on keeping warm (Lewis, 1982; Lloyd, 2006). Wider political and public attention was heralded by the 1991 publication of Brenda Boardman's Fuel Poverty: From Cold Homes to Affordable Warmth (Boardman, 1991). Boardman's work specifically defined fuel poverty, and some ten years later, informed much of the development of the UK's 2001 Fuel Poverty Strategy. Since then there has been a gradual realisation that fuel poverty is not unique to the UK nor is it confined to cool, damp climates such as the UK, Ireland and New Zealand that require heating for many months of the year. Indeed, Australia was amongst the first countries to fund investigations into fuel poverty in the 1980s prompted by market deregulation and associated questions of social equity (Energy Action Group, 2002), reminding us that 


\section{p. 2. Editorial: PPP special issue - International Perspectives on Fuel Poverty}

the cost of cooling the home can place equal strain on low income households. Recognition that some of the highest levels of excess winter deaths in Europe occurred in countries such as Greece and Portugal (Healy, 2003), widened the geographical focus of the debate further, providing additional challenge to the notion that fuel poverty does not exist in warm climates. In recent times, the focus of academic activity has extended to Eastern Europe, where fuel poverty has emerged as a major policy challenge following the fall of communism and the removal of subsidised fuel (Buzar, 2007a; 2007b).

In focussing on international perspectives on fuel poverty, this special issue aims to highlight the geographical and disciplinary breadth of the fuel poverty research community and to highlight the multidimensionality of the problem. In doing so, it is hoped that it will help challenge traditional associations between fuel poverty and cold damp climates and celebrate the inter-disciplinary nature of the field. Specifically the special issue focuses on three critical questions:

- How can fuel poverty be defined and understood in an international context?

- How is policy being framed and developed in different contexts?

- What areas remain under-researched or not well understood and what can an international perspective do to help address these lacuna?

The work of O'Sullivan et al at the University of Otago, for example, serves as a reminder of the powerful body of work to emerge from New Zealand regarding the physiological and psychosocial effects of low indoor temperatures and begins to address a conspicuous gap in the evidence base regarding the impact of fuel poverty on the health of children and young people. The paper presents new analysis which is used to underpin calls for an explicit policy focus on the alleviation of fuel poverty amongst households with children. Powell-Hoyland et al pick up the mantle from a UK perspective, looking in detail at asthma as one specific corollary of children's exposure to cold, damp homes. The paper provides insights into the lived experiences of fuel poverty, highlighting the daily juggling of priorities that goes on within fuel poor families and the associated consequences of the choices made for the health and wellbeing of the household.

The plight of another under researched group: occupants of Housing in Multiple Occupancy (HMOs) is highlighted in the contribution of Cauvain and Bouzarovski, which draws attention to the reduced rights, lack of control and stigmatisation suffered by this group, who may even lack access to basic domestic energy services. Through the development of a typology of $\mathrm{HMO}$, the authors draw attention to the heterogeneity of $\mathrm{HMO}$ provision and its occupants and call for more informed and nuanced policy debate in relation to this group so often overlooked by both the research and policy communities.

This special issue also considers the thorny issue of definitions of fuel poverty, a debate which has perennially exercised both policy and academic communities. The way fuel poverty is defined has important implications for policy formulation, not only for determining the scale and nature of the problem, but also for measuring progress towards its reduction (Moore, 2012). The papers by Simcock et al and Thomson shed light on particular aspects of the definition debate, which have previously received little attention within the literature. The former considers which energy-uses and services should form part of conceptualisations of fuel poverty, specifically considering whether non-heating energy uses and services should receive full recognition as contributors to fuel poverty. It is found that, at present, such uses have not permeated the discourses of mainstream policy makers and NGOs in relation to fuel poverty. Thomson et al then 
tackle the broader question of whether an EU wide definition is necessary and helpful, particularly in ensuring recognition of the problem as a prominent policy issue for all EU member states. In doing so, they challenge the European Commission's assertion that a pan-European definition would yield no benefits.

Continuing the European focus, Tirado-Herrero's paper fulfils two key purposes. First, it contributes much needed insights into the linkages between the European debt crisis and domestic energy affordability issues, using the case study of Spain. The case study approach is helpful in illuminating the variegated impact of structural level economic crises on more localised communities in terms of energy affordability. Second, the focus on Spain makes a further contribution towards dispelling myths about the existence of fuel poverty in Mediterranean countries, underlining how climatic conditions are merely one factor in a complex causal picture.

Together this collection of papers provides an excellent illustration of the breadth of research activity in relation to fuel poverty that is occurring around the world. Each paper shines light on a previously unexplored aspect of the problem or champions the cause of an under-researched group afflicted by fuel poverty. The quality of evidence underpinning each of papers makes this collection essential reading for all those engaged in better understanding and tackling fuel poverty around the world.

To conclude, we'd like to express our thanks to all that have contributed to this special issue, especially to the authors, reviewers and editorial assistants. We eagerly anticipate the debates their efforts open up and, as a multi-disciplinary policy journal, look forward to publishing future research on this and other pressing societal challenges.

* Corresponding address: Aimee Ambrose, CRESR, Sheffield Hallam University, Unit 10, Science Park, Howard Street, Sheffield, S1 1WB. Email: a.ambrose@shu.ac.uk

\section{References}

Boardman, B. (1991) Fuel Poverty: From Cold Homes to Affordable Warmth. London: Belhaven Press.

Buzar, S. (2007a) The 'hidden' geographies of energy poverty in post-socialism: between institutions and households. Geoforum, 38, 224-240.

Buzar, S. (2007b) When homes become prisons: the relational spaces of post-socialist energy poverty. Environment and Planning A, 39, 1908-1925.

Department of Energy and Climate Change (2015) Fuel Poverty Statistics. Available at: https://www.gov.uk/government/collections/fuel-poverty-statistics

Energy Action Group (2002) Provider of Last Resort: Can Vulnerable Electricity Customers be Protected in De-regulated Electricity Markets? Victoria, Australia: Energy Action Group.

Healy, J.D. (2003) Excess winter mortality in Europe: a cross-country analysis identifying key risk factors. Journal of Epidemiology and Community Health, 57, 784-789.

Lewis, P. (1982) Fuel Poverty Can Be Stopped. Bradford: National Right to Fuel Campaign.

Lloyd, B. (2006) Fuel Poverty in New Zealand. Wellington: Ministry of Social Development.

Marmot Review Team (2011) The Health Impacts of Cold Homes and Fuel Poverty. London: Friends of the Earth and the Marmot Review Team. 
p. 4. Editorial: PPP special issue - International Perspectives on Fuel Poverty

Moore, R. (2012) Definitions of Fuel Poverty: Implications for Policy. Energy Policy, 49, 19-26.

Office for National Statistics (2015) Excess winter mortality in England and Wales 2014/15. Available at: http://www.ons.gov.uk/peoplepopulationandcommunity /birthsdeathsandmarriages/deaths/bulletins/excesswintermortalityinenglandand wales/201415provisionaland201314final 